\title{
Comment to "Telaprevir Experience From Turkey”
}

\author{
Tarik Akar, ${ }^{1, *}$ Dilek Malkoc, ${ }^{1}$ and Selim Aydemir ${ }^{1}$ \\ ${ }^{1}$ Department of Gastroenterology, School of Medicine, Bulent Ecevit University, Zonguldak, Turkey \\ ${ }^{*}$ Corresponding Author: Tarik Akar, Department of Gastroenterology, School of Medicine, Bulent Ecevit University, 67600 Kozlu, Zonguldak, Turkey. Tel: +90-5054192900, Fax: \\ +90-3722612392, E-mail: drtarikakar@gmail.com
}

Received 2015 May 12; Accepted 2015 May 22.

Keywords: Adverse Effects, Hepatitis C, Telaprevir, Turkey

\section{Dear Editor,}

We have read with great interest the article entitled "Telaprevir experience from Turkey" by Komur et al. recently (1).

First of all, we have applauded the efforts of the authors and the editors of journal for putting forward this controversial and wondered topic for us. Currently, the hepatitis $C$ treatment is in a very dynamic situation, due to newly introduced potent drugs. Therefore, the most popular guidelines (AASLD, EASL and APASL) have constantly updated the treatment recommendations, based on the new evidences from the effects and side-effects of these drugs (2). Thereby, every comment on novel potent drugs is very important for the clinicians, who have insufficient experience with them. We firstly want to discuss the content of the article and present to our experience that selected patients are more difficult to treat as a group, with different and strange side-effects.

At the end of the article, the authors concluded that triple therapy with telaprevir has still been promising for difficult to treat patients, despite that telaprevir has severe and frequent adverse effects. First, patients selected as the treatment group were not completely acceptable as a difficult to treat patient group, as most of the patients $(80.7 \%)$ had relapse condition, which is the most suitable patient for telaprevir treatment, whereas only a small group, five patients, were non-responder and one patient had compensated cirrhosis, and all have been acceptable as difficult to treat group, in that article. Second, despite of the treatment group was formed by well-selected patients, the rate of hospitalization, which constituted $38 \%$ of all the patients, seems to be very high.

As for our experience, we treated 16 patients with compensated cirrhosis or fibrosis stage 4 and above. All patients had genotype 1 and were treatment experienced. The age range was 60 - 82 years old. Those with advanced age and comorbidities, having a suitable condition, according to CUPIC study for telaprevir (platelet >
$100.000 / \mathrm{mm}^{3}$ and albumin $>3.5 \mathrm{~g} / \mathrm{dL}$ ) were treated due to the risk of rapid clinical deterioration and persistent elevated liver enzymes ( $>x^{2}$ the normal) (3). As expected, the sustained virologic response (SVR) was lower and relapse rate was higher than in Komur's group, 62.5\% and $5 / 15$, respectively. Unlike in this article, several serious and bizarre side-effects were observed during therapy. For one patient (65 years old, compensated cirrhosis, diabetes and asthma), 14 units of blood were required, during telaprevir treatment. In one patient, telaprevir related drug reaction with eosinophilia and systemic symptoms (DRESS) syndrome and severe salmonella infection were observed and required hospitalization for 34 days (4). The SVR was obtained in the mentioned two patients, despite these severe side-effects. However, one patient (74 years old, non-responder, alcoholic liver disease) died on the 4 th week of telaprevir treatment, due to urinary sepsis. It was not fully understood whether there was a relationship with telaprevir or alcohol. In another problematic patient (82 years old, nonresponder, compensated cirrhosis, severe elevated liver enzyme), the telaprevir treatment was discontinued due to development of decompensation (ascites and encephalopathy). The most interesting patient was a 67 years old woman, who had a swelling under the right armpit, during the 8th week of telaprevir treatment. A computed tomography revealed a $5 \mathrm{~cm}$ mass, considered to be a packet of lymphadenopathy. After the excisional biopsy examination, tuberculosis was diagnosed, displaying the granuloma formation and necrosis. This case is the second case of tuberculosis observed during treatment with telaprevir $(4,5)$.

In conclusion, telaprevir based triple therapy is not appropiate for all hepatitis $C$ patients, especially in patients with cirrhosis and problems experienced in the dual therapy, due to intolerable side-effects. For the difficult to treat group, new potent drugs, like Sofosbovir and Le-

Copyright ( ) 2015, Kowsar Corp. This is an open-access article distributed under the terms of the Creative Commons Attribution-NonCommercial 4.0 International License (http://creativecommons.org/licenses/by-nc/4.0/) which permits copy and redistribute the material just in noncommercial usages, provided the original work is properly cited. 
dipasvir, must absolutely be chosen for better treatment response and less side-effects.

\section{Footnote}

Authors' Contribution:Tarik Akar and Selim Aydemir searched the literature and wrote, Dilek Malkoc had the first idea and made the English correction and review.

\section{References}

1. Komur S, Kurtaran B, Inal AS, Pullukcu H, Ulu A, Kuscu F, et al. Telaprevir experience from Turkey. Hepat Mon. 2015;15(2):e25639. doi:10.5812/hepatmon.25639. [PubMed:25788959]
2. European Association for Study of L. EASL Clinical Practice Guidelines: management of hepatitis C virus infection. J Hepa tol. 2014;60(2):392-420. doi: 10.1016/j.jhep.2013.11.003. [PubMed 24331294]

3. Hezode C, Fontaine H, Dorival C, Larrey D, Zoulim F, Canva V, et al Triple therapy in treatment-experienced patients with HCV-cirrhosis in a multicentre cohort of the French Early Access Programme (ANRS CO20-CUPIC) - NCT01514890. J Hepatol. 2013;59(3):434-41. doi:10.1016/j.jhep.2013.04.035. [PubMed: 23669289]

4. Akar T. Telaprevir-Induced DRESS Syndrome Associated With Salmonella typhi. ACG Case Reports J. 2015;2(2):79. doi: 10.14309| crj.2015.10.

5. Rodriguez-Medina B, Blanes M, Vinaixa C, Aguilera V, Rubin A, Prieto M, et al. Haemophagocytic syndrome in a liver transplant patient during treatment with Telaprevir. Ann Hepatol. 2013;12(6):974-8. [PubMed: 24114830] 